IQTISHADIA

13,2

258

\title{
Board Characteristics, Type of Insurance And Performance in Indonesia Sharia Insurance Companies
}

\author{
Hikmah Endraswati \\ Sunan Kalijaga State Islamic University of Yogyakarta, Indonesia \\ h_endraswati@yahoo.co.id \\ 197705072000032001@uin-suka.ac.id \\ Bayu Tri Cahya \\ Kudus State Islamic Religion Institute, Indonesia \\ cahyab38o@gmail.com
}

\begin{abstract}
The purpose of this study is to examine the influence of the board characteristics on the performance of Indonesian sharia insurance companies with insurance types as moderating variable. The board characteristics in this study are the size of board directors, the size of board commissioners, the proportion of women in board directors, and the proportion of women in board commissioners. This study uses 22 sharia insurance business units as a sample with the period of 2014-2019. We use purposive sampling as a sampling technique. Multiple regression with split sample was used in this research as technical analysis. The results showed that the size of the board directors influence performance negatively. In addition, the type of insurance moderate the influence size of board directors and the proportion of women as directors on performance. There are differences for size of the board of commissioners and the proportion of women as board commissioners.
\end{abstract}

Keywords: Board, Performance, Sharia business unit, Sharia insurance, Corporate governance.

\section{INTRODUCTION}

Sharia Insurance in Indonesia began with the Takaful Insurance on $5^{\text {th }}$ May 1994. Sharia insurance has been developed sufficiently for 26 years. However, after 26 years of being established and developing, the sharia insurance market share is not much different from sharia banks which is only $6.6 \%$ on November 2019 and has experienced slowdown in asset growth since 2018. The growth of sharia insurance industry assets in 2019 was 8.44\%, where sharia life insurance grew $8.74 \%$, sharia general insurance grew 5.02\%, and sharia reinsurance grew $13.35 \%$. The growth of these assets was influenced 
by the growth of national contribution income of $8.69 \%$, where sharia life insurance increased $9.76 \%$, sharia general insurance contracted $1.08 \%$, and Characteristics, sharia reinsurance increased 15.44\% (www.republika.co.id, 2020).

Type of Insurance

Insurance performance is important to be researched because the performance shows the company's result and achievement and it is the main concern of the owner and stakeholders of the company. After cases which were happened in conventional government-owned insurances such as Jiwasraya and Bumiputera due to weak internal and external monitoring, research on the relationship between corporate governance and insurance performance in this case of sharia insurance becomes necessarily to do.

Research on insurance performance previously has been carried out by several researchers who have linked to financial ratios such as Suherman, Firmansyah, Almunawwaroh (2019) in Indonesia, Ulfan (2017) in Indonesia, AlNemer (2016) in Saudi Arabia, Utami (2016) in Indonesia, Handayani (2015) in Indonesia, Mandira (2014) in Indonesia, Hasbi (2013) in Indonesia, Joo (2013) in India, Patel (2013) in India, Putri and Lestari (2014) in Indonesia. The others examine the relationship between corporate governance and insurance performance (Pramono, 2019 in Indonesia, Hidayat and Firmansyah, 2017 in Indonesia; Fekadu, 2015 in Ethiopia; Dhouibi, 2013 in Tunisia).

The relationship between corporate governance especially in characteristics of the board to the performance of sharia insurance is important to be researched because board has responsibility for the performance of company. The board in this research refer to board of directors that run the company every day and the board of commissioners that monitor and supervise the directors in running the company. In addition, research on the relationship of corporate governance and insurance performance is still limited in Indonesia.

The results of Fekadu's (2015) research in the Ethiopian insurance industry showed that board size and board diversity had a negative effect on performance. This is different from Hidayat and Firmansyah (2017) who conducted research on sharia insurance companies in Indonesia during 2011-2015. The results of their study showed that the size of board directors did not influence on the financial performance of Islamic insurance. Other results showed that the Board of Commissioners influence the financial performance of sharia insurance negatively, which was contrary to Tertius and Christiawan (2015) who found that the Board of Commissioners did not 
IQTISHADIA

13,2 
The relationship between board and the performance of sharia insurance in these research uses agency theory. According to agency theory the relationship or contract between the owner and manager raises agency problem due to differences in interests (Jensen and Meckling, 1976). The Type of Insurance owners want the manager to act in the interests of the owner but the manager has opportunities to make decisions that benefit himself. Agency problems will raise as problems in the achievement of company performance.

The concept of corporate governance is used to overcome the agency problem especially is the structure of corporate governance. The structure of corporate governance in this study refers to the existence of board directors and commissioners. Board of Directors as the party who runs the company's operations every day. Board of Commissioner as the party that carries out the supervisory and monitoring function to the directors.

Agency theory used three basic assumptions namely human assumption, organizational assumption, and informational assumptions (Eisenhardt, 1989). This study uses size of board directors as an independent variable to fulfill human assumptions. This assumption states that humans basically have a selfish nature, limitations of rationality and are risk-averse. The size board of directors fulfills these assumptions in relation to the limitations of rationality. Because the greater size board of directors, the more expertise they have, the wider network coverage both internally and externally and the better competence so that the decisions taken by the directors are better too. The greater size of board directors, the better the company's performance (Dhouibi, 2013). Datta (2018) supported the effect of board size on the performance of insurance companies in Bangladesh for the periode 20102016. This is in line with Khan, Arman, Eneizan (2019) in Pakistan for the periode 2010-2015.

The positive effect of size board directors on performance was also found by Kader, Adams, Hardwick, and Kwon (2014) in 50 companies with the period of research 2005-2007 in 17 Islamic countries. The result of the study was confirmed by Najjar (2012) who conducted research on insurance companies in Bahrein during the period 2005-2010. The same result was stated by Tornyeva and Wereko (2012) in the Ghana insurance company in the period 2005-2009, so the hypothesis in this study is:

$\mathrm{H}_{1}$ : The size board of director has a positive impact on performance of sharia insurance business units. 
IQTISHADIA

13,2 with the size of board directors. The size board of commissioners fulfills human assumptions namely the limitations of rationality in agency theory. The greater size of board commissioners, the better the supervisory function is because more personnel are involved in the supervision, so the company's performance increases.

The perspective that the greater members of board commissioners, the better performance also be seen from resource dependence. The greater size board of commissioners shows that there is a diversity of expertise, knowledge and skills that are useful in providing advice to the directors and monitoring the performance of them (Al Amameh, 2014). The existence board of commissioners as the implementation of corporate governance mechanism will improve company performance with the existence of an advocate function from the commissioners. The greater size Board of Commissioners will increase company performance, but if the size is too large will reduce company performance. This is caused by difficulties in the coordination function (Hidayat and Utama, 2015).

The positive influence of board commissioners' size and company performance was documented by Hidayat and Firmansyah (2017) who examined 15 sharia insurances in Indonesia during the 2011-2015 period and found that the size of board commissioners had a positive effect on the performance of sharia insurance in Indonesia. The study confirmed Ahmad, Tariq, Hamad and Samad (2014) in Pakistan, Widagdo and Chariri (2014) in Indonesia non-financial companies, and Putra (2015) in 100 Indonesia manufacturing companies for the period of 2010-2013 so that the hypotheses in this study is:

$\mathrm{H}_{2}$ : The size board of commissioner has a positive impact on performance of sharia insurance business units.

The proportion of women in board of directors and boards of commissioners is to fulfill human assumptions in agency theory mainly the limitations of rationality. The increasing proportion of women on the board of directors and the board of commissioners shows that the company fulfills social, moral and ethical concerns by involving women in the board of directors as decision makers and as commissioners who have the authority to monitor, so that the company's reputation increases and encourages better company performance (Ibrahim, Ouma, and Koshal, 2019). 
Liu, Xie and Wei (2014) documented positive influence of gender diversity on company performance in China. The results of the study were confirmed by Low, Roberts and Whiting (2015) who conducted research in Hong Kong, South Korea, Singapore and Malaysia. García-Meca, Sánchez, and Ferrero (2015) agree that gender diversity strengthen company performance with a sample of 159 companies in 9 countries in the period of 2004-2010. Characteristics, Type of Insurance They also stated that weak regulation and protection to investors in a country caused the influence of gender diversity on company performance was weak. The result of this study was supported by Amore and Garofalo (2016) who conducted research in the US for 1994-2006. They proved that the company has good performance stability with the presence of female directors even though the level of business competition is very tightly. Based on the theory and results of previous studies, the hypothesis in this study are:

$\mathrm{H}_{3}$ : The proportion of women on the board directors has a positive impact on performance of sharia insurance business units.

$\mathrm{H}_{4}$ : The proportion of women on the board commissioners has a positive impact on performance of sharia insurance business units.

The type of insurance in this study as a moderating variable that is a variable that can strengthen or weaken the influence of the independent variable (size of board directors, size of board commissioners, proportion of women as directors, proportion of women as commissioners) to the dependent variable (performance of sharia insurance business units). The type of insurance as a moderating variable is based on previous research that found the influence of industry types and company types on company performance (Ruefli and Wiggins, 2003; Raza, Farooq and Khan, 2011; Houthoofd and Hendrickx, 2012). Matyjas (2014) supported the results of previous studies that the type of company affects the performance of 387 companies on the Warsawa Stock Exchange during the 2007-2010 period. Ortynski (2016) confirmed that company-specific characteristics affect the performance of companies in Poland insurance companies during the period 2006-2013.

The type of insurance as a moderator variable refers to Memon, Cheah, Ramayah, Ting, Chuah, and Cham (2019) which state that categorical variables such as country type, gender, type of university, and type of industry can be used as moderation variables. Previous research conducted by Nataraj (2020) in India used bank types as moderating variables. Sugianto (2017) uses other categorical variables such as gender, age and income as moderating variables in Indonesia. 
IQTISHADIA

13,2

264

In addition, the type of insurance as a moderator is based on the opinion that this type of insurance offers different products that have different characters and different consumers so it can strengthen or weaken the influence of board characteristics on company performance. Based on the theory and previous studies, the hypotheses of this study are:

$\mathrm{H}_{5}$ : The type of insurance moderates the influence of the size board directors on the performance of sharia insurance business units.

$\mathrm{H}_{6}$ : The type of insurance moderates the influence of the size board commissioners on the performance of sharia insurance business units.

$\mathrm{H}_{7}$ : The type of insurance moderates the influence of the proportion women as board directors on the performance of sharia insurance business units.

$\mathrm{H}_{8}$ : The type of insurance moderates the influence of the proportion women as board of commissioners on the performance of the sharia insurance business units.

The conceptual framework of this study is described as follows

\section{Figure 1}

\section{Conceptual Framework of The Research}

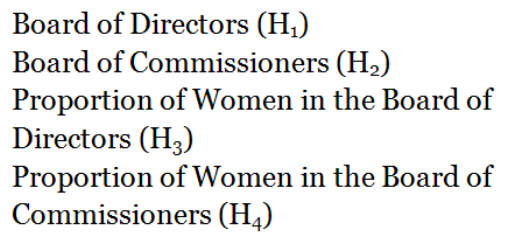

\section{RESEARCH METHOD}

The population of this study is the sharia insurance business units which are registered in the OJK during the 2014-2019 period in Indonesia. The sampling technique is purposive sampling, so that the number of samples that met the criteria in this study are 22 sharia insurance business units. The research data is taken from the company's annual report, so the type of data is included in the secondary data. 


\section{Operational Definition of the Variables and Measurements}

The size of board of directors (BoD) is the number of members board of directors in company at a certain time (Beasley, 1996; Cheng, Evans and Nagarajan, 2008). To measure the size of board directors refers to Datta (2018), Dhouibi (2013), Wijayanti and Mutmainah (2012), Cheng et al. (2008), and Beasley (1996).

Size of BoD $=$ Number of members board directors at a certain time

The size of the board of commissioners (BoC) is the number of members board commissioners in the company at a certain time (Brick and Chidambaran, 2010). To measure the size of the Board of Commissioners refers to Hidayat and Utama (2015), Robin and Amran (2016), Widagdo and Chariri (2014), and Fernandez (2015).

Size of $\mathrm{BoC}=$ Number of members board commissioners at a certain time

The proportion of women in Board of Directors is how many women as directors compared to the number of directors (Frieze, Olson and Good, 1990). The measurement of the variable refers to Endraswati (2018), Putra (2015), Marinova et al. (2010), Dervish (2009), and Frieze et al. (1990).

\section{The number of women as directors \\ Proportion of women in $\mathrm{BoD}=$ \\ Number of directors}

Board

Characteristics, Type of Insurance

The proportion of women in the Board of Commissioners is how many women as members of commissioners compared to the number of commissioners (Frieze et al., 1990). The measurement of the variable refers to Iunascu, Sacarin and Minu (2018), Suhardjanto et al. (2017), Endraswati (2016), and Frieze et al. (1990).

Proportion of women in $\mathrm{BoC}=\frac{\text { Number of women as commissioners }}{\text { Number of commissioners }} \times 100 \%$

The measurement of performance in this study uses Risk Based Capital. Risk Based Capital (RBC) according to the National Association of Insurance Commissioners (NAIC) is a method used to determine the adequacy of a company's capital so it will not harm its customers when a loss occurs due to the deviation of asset and liability management by considering size and risk. Minimum solvency level according to POJK No. 72/POJK.05/2016 about the 
IQTISHADIA financial health of sharia insurance companies and reinsurance companies is $13,2120 \%$. The formula for calculating RBC in this study refers to Cummins and Phillips (2009), Nasution, Adiba, and Abdulrahim (2019), Pramestika (2019), Sumartono and Harianto (2018), Leviany and Sukiati (2014) as follows:

$R B C=\frac{\text { Wealth permitted }- \text { liability }}{\text { Minimum Solvency Level Limits }} \times 100 \%$

The analysis technique used to meet the objectives of this study is multiple regression analysis with split samples based on the type of insurance. This method referes to Ghozali (2011) and Ning and Alikaj (2019). The equation model is used as follows:

$\mathrm{RBC}=\beta_{\mathrm{o}}+\beta_{1} \mathrm{UD}+\beta_{2} \mathrm{UDK}+\beta_{3} \mathrm{GD}+\beta_{4} \mathrm{GDK}+\varepsilon$

Where:

$$
\begin{array}{ll}
\text { RBC } & : \text { Risk Based Capital } \\
\beta_{\mathrm{o}} & : \text { Constant } \\
\beta_{1-4} & : \text { The coefficient of the independent variable } \\
\text { UD } & : \text { Board of Directors' Size } \\
\text { UDK } & : \text { Board of Commissioners' Size } \\
\text { GD } & : \text { Proportion of Women in the Board of Directors } \\
\text { GDK } & : \text { Proportion of Women in the Board of Commissioners } \\
\varepsilon & : \text { Residual Variable or Prediction Error }
\end{array}
$$

Hypothesis testing in this research by looking at the significance value in the $t$ test. If the significance is less than 0.05, then the hypothesis is accepted and vice versa. Before multiple regression analysis is performed, researchers test the classical assumptions to meet the aspects of normality, multicollinearity, heteroscedasticity, and autocorrelation.

\section{RESULTS}

The results of the study are presented in the form of descriptive statistics and hypothesis testing. Descriptive statistics provide an overview of the mean, maximum and minimum values of each variable used in this study. 
Table 1

Descriptive Statistics of General and Other Sharia Business Units in Indonesia

Characteristics,

\begin{tabular}{cccccc|ccccc}
\hline \multicolumn{7}{c|}{ General insurance } & \multicolumn{5}{c}{ Other Insurance } \\
\hline & $\mathrm{n}$ & Min & Max & Mean & Std Dev & $\mathrm{n}$ & Min & Max & Mean & Std Dev \\
\hline RBC & 66 & -1463 & 940 & 182.85 & 295.57 & 66 & 35 & 8903 & 1064.31 & 1560.49 \\
UD & 66 & 3 & 6 & 4 & 0.92 & 66 & 3 & 7 & 4 & 1.18 \\
UDK & 66 & 3 & 9 & 4 & 1.18 & 66 & 3 & 6 & 4 & 0.94 \\
GD & 66 & 0 & 50 & 14.65 & 16.49 & 66 & 0 & 50 & 25.5 & 16.41 \\
GDK & 66 & 0 & 50 & 13.61 & 17.23 & 66 & 0 & 50 & 16.31 & 15.36 \\
\hline
\end{tabular}
Type of Insurance

Source: Data is processed from financial statements

Based on Table 1 above, it can be seen that the RBC value of each sharia general insurance business units during the study period have minimum value is $-1463 \%$ and maximum value is $940 \%$ and an average value is $182.85 \%$. Other insurance business units have minimum value is $35 \%$ and a maximum value is $8903 \%$ and an average value is $1064.31 \%$. This shows that there is a sharia insurance business unit that has not met the solvency standard in accordance with OJK regulations, namely: POJK No. 72/POJK.05/2016. Regulations in Indonesia before 2016 refer to KMK regulation No. 424/ KMK.06/2003 which both of them set the minimum solvency ratio is $120 \%$.

Regulations about size of Board Directors and Board of Commissioners in insurance company are in POJK No.2/POJK.05/2014 and POJK No.73/ POJK.05/2016 which states that the size of board directors and the size of Board of Commissioners must be a minimum of three persons. We can see that based on the descriptive statistical results in Table 1 above, all sharia insurance business units, both general and other insurance, have fulfilled the existing regulatory requirements.

The proportion of women in the Board of Directors and the Board of Commissioners has not been regulated in insurance corporate governance regulation. Because there is no regulation yet, the majority of sharia insurance business units do not involve women either in the composition of the directors or commissioners. Based on Table 1 above the minimum value is still $0 \%$ and the maximum value is $50 \%$ with the average proportion of

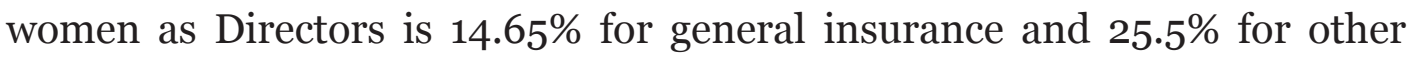
insurance. A smaller percentage is in the proportion of women as Board of Commissioners with an average is $13.61 \%$ for general insurance and $16.31 \%$ for other insurance.

To test the hypotheses, researchers have tested classical assumptions namely normality, multicollinearity, heteroscedasticity and autocorrelation. 
IQTISHADIA

13,2

The results of the classic assumption test in this study have fulfilled normality, no multicollinearity, no heteroscedasticity and no autocorrelation. Furthermore, researchers conducted multiple regression analysis by splitting the sample based on the type of insurance business into two namely: general insurance and other insurance.

Table 2

Results of Multiple Regression Analysis

\begin{tabular}{ccccccc}
\hline \multirow{2}{*}{ Variables } & \multicolumn{2}{c}{ Pool Data } & \multicolumn{2}{c}{ General Insurance } & \multicolumn{2}{c}{ Other Insurance } \\
& Coefficient & Prob & Coefficient & Prob & Coefficient & Prob \\
\hline Constanta & 1228.78 & 0.028 & 50.32 & 0.800 & 2189.41 & 0.046 \\
UD & -282.87 & $0.009^{* * *}$ & -41.42 & $0.040^{* *}$ & -366.92 & $0.049^{* *}$ \\
UDK & 91.55 & 0.349 & 30.42 & 0.325 & 67.12 & 0.744 \\
GD & 63.01 & $0.024^{* *}$ & 44.65 & $0.001^{* * *}$ & 9.45 & $0.065^{*}$ \\
GDK & 105.74 & 0.875 & -273.57 & 0.281 & 10.53 & 0.437 \\
Adjusted R-squared & 0.234 & & 0.242 & & 0.128 \\
F-Statistic & 2.15 & $0.049^{* *}$ & 3.04 & $0.024^{* *}$ & 1.46 & $0.044^{* *}$ \\
\hline
\end{tabular}

Source: Data ${ }^{* * *},{ }^{* *},{ }^{*}$ significant at $\alpha=1 \%, 5 \%$ and $10 \%$

The adjusted R-Squared value for pool data in Table 2 shows $23.4 \%$. It means that the variable size of Board Directors, size of Board Commissioners, the proportion of women in the board of directors and the proportion of women in the Board of Commissioners can explain $23.4 \%$ variation in the performance of the sharia insurance business unit and the remaining $76.6 \%$ is explained by other variables which are not examined in this study. The adjusted R-Squared value in Table 2 for general insurance is $24.2 \%$. It means that the variation in the performance of the sharia general insurance business unit can be explained by the variable size of directors, size of board commissioners, the proportion of women as directors and the proportion of women as commissioners is $24.2 \%$ and the remainder $75.8 \%$ is explained by other variables which are not used in this study. The adjusted R-squared value for other insurance is $\mathbf{1 2 . 8 \%}$. It means that the variation in the performance of other sharia insurance business units can be explained by size of board directors, size of board commissioners, the proportion of women as directors, and the proportion of women as commissioners is $12.8 \%$ and the remaining $87.2 \%$ is explained by other variables which are not used in this study.

The $\mathrm{F}$ value in Table 2 shows the probability of 0.049 for data pool, 0.024 for general insurance and 0.044 for other insurance. Because the probability value is smaller than 0.05 , it can be said that the variable size of directors, size of commissioners, the proportion of women as directors and the proportion of women as commissioners jointly influence the overall insurance performance, as well as when the type of insurance is separated into general insurance and others. 
The size of board director variable has a coefficient value of -282.87 (negative) with a significance value of 0.009 which this value is less than 0.05 Characteristics, so $\mathrm{H}_{1}$ is not supported. It means that the greater the board size, the lower the Type of Insurance performance of sharia insurance business unit.

The size of Commissioners variable has a coefficient value of 91.55 (positive) with a significance value of 0.349 where this value is more than $0.05 \mathrm{so}_{2}$ is not supported. It means that the size of Board of Commissioners does not affect the performance of the sharia insurance business unit.

The variable proportion of women as directors has a coefficient of 63.01 (positive) with a significance value of 0.024 which this value is less than 0.05 so $\mathrm{H}_{3}$ is supported. It means that the proportion of women as directors has a positive effect on the performance of the sharia insurance business unit.

The variable proportion of women as commissioners has a coefficient of 105.74 (positive) with a significance value of 0.875 where this value is greater than 0.05 so $_{4}$ is not supported. It means that the proportion of women as commissioners does not have a positive effect on the performance of the sharia insurance business unit.

To test the moderating variable by comparing the adjusted R-squared value and seeing the significance of the variable. The adjusted R-squared value for sharia general insurance business units is $24.2 \%$ and for other sharia insurance business units is $12.8 \%$. Based on Table 2 above the size of directors has a coefficient of -41.42 (negative) with a significance value of 0.040 for sharia general insurance business units and a coefficient of -366.92 (negative) with a significance value of 0.049 where this value is less than 0.05 so it can be said that $\mathrm{H}_{5}$ is supported. This means that the type of insurance moderates the influence of size board directors on the performance of sharia insurance business unit in Indonesia. Based on the coefficient value, the effect of the size board directors on performance is stronger in the sharia general insurance business unit group compared to other sharia insurance business unit groups.

The size of board commissioners has a coefficient of 30.42 (positive) with a significance value of 0.325 for sharia general insurance business units and a coefficient of 67.12 (positive) with a significance value of 0.744 for other sharia insurance business units which this value is greater than 0.05 so it can be said that $\mathrm{H}_{6}$ is not supported. This means that the type of insurance does not moderate the influence of size board commissioners on the performance of sharia insurance business units in Indonesia. 
IQTISHADIA

13,2

270

The proportion of women as directors has a coefficient of 44.65 (positive) with a significance value of 0.001 for the sharia general insurance business unit and a coefficient of 9.45 (positive) with a significance value of 0.065 for other sharia insurance business units which this value is less than 0.10 so it can be said that $\mathrm{H}_{7}$ is supported. This means that the type of insurance moderates the effect of the proportion of women as directors on the performance of the sharia insurance business unit in Indonesia. Based on the coefficient value, the influence of the proportion of women as directors on performance is stronger in the sharia general insurance business group compared to other sharia insurance business unit.

The proportion of women as board commissioners has a coefficient of -273.57 (negative) with a significance value of 0.281 for the sharia general insurance business unit and a coefficient of 10.53 (positive) with a significance value of 0.437 for other sharia insurance business units which this value is greater than 0.05 so it can be said $\mathrm{H}_{8}$ is not supported. This means that the type of insurance does not moderate the effect of the proportion of women as commissioners on the performance of sharia insurance business units in Indonesia.

\section{DISCUSSION}

Based on the results of hypothesis testing above, $\mathrm{H}_{1}$ which states that the size of board directors influence on the performance of sharia insurance business units positively is not supported in this study. The result of this study is in line with Wijayanti and Mutmainah (2012) in Indonesia, Fekadu (2015) in the Ethiopian insurance company, Mollah and Zaman (2015) in Indonesia, Sanyaolu, Adesanmi, Imeokparia, Sanyaolu, and Alimi (2017) in Nigerian banking, Ionascu, Ionascu, Sacarin and Minu (2018) in Romania, Lee, Cheng, Har, Nassir, Razak (2019) at Takaful insurance company in Malaysia. This result can be caused by the greater size of board directors, the agency problems that arise will also be even greater. In addition, the greater number of board directors, the more difficult to reach an agreement because of differences in views on a problem. This will affect the company's performance. The result of this study is different from Najjar (2012) in Bahrain, Dhouibi (2013) in Tunisia, Tornyeva and Wereko (2012) in Ghana, Widagdo and Chariri (2014) in Indonesia, Fernandez (2014) in Europe, Hidayat and Utama (2015) in Indonesia, Hidayat and Firmansyah (2017) in Indonesia, Datta (2018) in Bangladesh, Khan, Arman and Eneizan (2019) in Pakistan. 
The results of the study in Table 2 also show that $\mathrm{H}_{2}$ is not supported. It means that size of Board Commissioners does not affect the performance of the sharia insurance business unit in Indonesia. This is consistent with research conducted by Darwis (2009), Kusumawati and Hermawan (2013), Tertius and Christiawan (2015), Putra (2015), Robin and Amran (2016), Firmansyah and Fadillah (2019) in Indonesia. The result of this study can be caused by the main task of Board Commissioners is to monitor and provide advice to the directors. The Board of Commissioners is not responsible for the daily operations of the company. In addition, the Board of Commissioners does not come every day to the company to conduct monitoring. In the case of Indonesia, the oversight function of financial institutions, apart from the Board of Commissioners, is also carried out externally by the OJK so that the size of Board Commissioners does not affect the company's performance. The results of this study do not confirm previous studies such as Hassan, Rizwal and Sohail (2017) in Pakistan, Hidayat and Firmansyah (2017) in Indonesia, Putra (2015) in Indonesia with different company performance measures namely Tobins Q and Fernandez (2014) who conducted research at EUROSTOXX50.

The third hypothesis which states that the proportion of women as directors has a positive effect on the performance of sharia insurance business units in Indonesia is supported in this study. The ability of women directors to create more open discussions in expressing their opinions, collaborative team and provide different perspective has a positive impact on corporate policy making so that company performance increases (Fairfax, 2006). In addition, female directors are considered to provide an active role and greater power in the company than male directors (Virtanaen, 2012). The result of this study confirms researches were conducted by Sanyaolu, Adesanmi, Imeokparia, Sanyaolu, and Alimi (2017) in Nigerian banking, Ionascu, et al. (2018) in Romania, Amore and Garafalo (2016) in the US, García-Meca, Sánchez, and Ferrero (2015), Liu, Xie and Wei (2014) in China and Low, Roberts and Whiting (2015) in Hong Kong, South Korea, Singapore and Malaysia. This is different from the result of research were conducted by Endraswati (2018) on Islamic banking in Indonesia, Kramaric, Aleksic and Pejic-Bach (2018) in the Croatian insurance company, Fekadu (2015) in Ethiopia, Ujunwa et al. (2012) in Nigeria, Marinova et al. (2010) in the Netherlands and Denmark.

The proportion of women as commissioners does not affect the performance of sharia insurance business units in Indonesia so $\mathrm{H}_{4}$ is not supported in this study. This can be caused by one of the local factors in 
IQTISHADIA Indonesia namely the culture, where women are more demanding role in 13,2 domestic affairs than public affairs. In addition, the absence of regulations governing the involvement of women as commissioners in Indonesia causes 272 the portion of women as commissioners to be minimal. This can be seen from the average proportion of women as commissioners for the sharia general insurance business unit is $13 \%$ and for other sharia insurance is $16 \%$. The result of this study supports previous research conducted by Marinova et al. (2010) in Netherlands and Denmark, Endraswati (2016) in Indonesia, Suhardjanto et al. (2016) in Indonesian and Pakistani mining companies, Kramaric, Aleksic and Pejic-Bach (2018) in Croatian insurance companies, and Shabbir (2018) in Italy and meanwhile are different from the results of research conducted by Anderson and Upadhyay (2011) in the US , Dobbin and Jung (2011) in US and Ujunwa et al. (2012) in Nigeria.

Based on the results of the study in Table 2 shows that the type of insurance moderates the influence of size board of directors on the performance of sharia insurance business units in Indonesia so $\mathrm{H}_{5}$ is supported in this study. This shows that the type of insurance that is divided into general and other sharia insurance business units that are part of the sub-industry's characteristics can strengthen or weaken the influence of size board of directors on performance. This is supported by the different nature of the product between general insurance and other insurance (for example life and health insurance). Sharia general insurance business unit is the insurance which provides compensation in the event of a loss in property such as theft and accident, so that the type of sub-industry is more complex when compared to life insurance and health insurance. In addition, this also relates to the duties of directors who have the responsibility of making policies and running the daily operations of the company. Sub industrial type as a moderating variable is also used by Nataraj (2020) with different studies. Nataraj (2020) in his research used a type of bank as a moderator.

Thistype of insurancemoderatesthe effect of sizeboard of commissioners on the performance of sharia insurance business units in Indonesia as $\mathrm{H}_{6}$ is not supported in this study. This can be caused by the monitoring function performed by the board of commissioners which does not have difference for the type of sub-industry, especially insurance. This study uses sharia insurance business units a sample in this research so that are relatively small in size and complexity, so that the monitoring function is not as complex as in sharia or conventional insurance. In addition, the function of the Board of Commissioners as monitoring the work of directors is also assisted by an external party namely OJK. 
The seventh hypothesis states that type of insurance moderates the influence proportion of women as directors on the performance of sharia insurance business unit in Indonesia is supported in this study. This is due to different nature types of sub-industries, namely the complexity of sharia general insurance business unit and other sharia (life and health) insurance business units are more specific and the role of gender as directors itself in the Type of Insurance company. This type of sub-industry as moderating is also used by Memon et al. (2019) and Nataraj (2020). Women as directors in the case of sharia general insurance business unit in Indonesia is $14 \%$ and for other sharia insurance business unit is $25 \%$ based on the descriptive statistics in Table 1 . The minority of women as directors is seen as a challenge to completing their duties properly. This is one of the triggers for increasing company performance.

Furthermore, the latter for $\mathrm{H}_{8}$ which states that the type of insurance moderates the influence proportion of women as a board of commissioners on the performance of sharia insurance business unit in Indonesia is not supported in this study. This can be caused by the monitoring function carried out by the Board of Commissioners for sharia insurance business units with different types of sub-industries sharia insurance are not found differences. This means that monitoring on the sharia general insurance unit and other sharia insurance units (life and health) is the same. The proportion of women as a Board of Commissioners is still small with an average of $13 \%$ for the sharia general insurance business unit and $16 \%$ for other sharia insurance business units so that it has not made yet a significant contribution in terms of monitoring. The monitoring function of the Board of Commissioners is generally assisted by external parties, namely OJK and external auditors.

\section{CONCLUSIONS}

Based on the results of the analysis in this study, it can be concluded that insurance companies are required to meet the rules regarding the minimum size of directors and commissioners are determined by OJK. Sharia insurance business units should be careful when adding the number of the board directors because based on this study the greater size of the directors, the lower the performance of sharia insurance business unit. This can be caused by the bigger size of the boards, the bigger agency problem that will arise. Furthermore, the bigger size of the boards means that there are difficulties to coordinate and make an agreement because the differences in perspectives. The results of this study also indicate size Board of Commissioners should 
IQTISHADIA

13,2

274

refer to the regulations are formulated by OJK because the addition number Board of Commissioner in this study does not affect the performance of the sharia insurance business unit.

Meanwhile, the proportion of women as directors needs attention, even though it has not been regulated in the OJK regulation regarding the percentage of women as directors, it is better for sharia insurance business units to consider the portion of women's contributions as directors on company performance. Because based on this study the proportion of women as directors has positive effect on the performance of the sharia insurance business unit. This is due to the ability of female directors to create more open and collaborative discussions and to be able to provide different perspectives. This ability has a positive impact on company policy decision so the performance of sharia insurance business unit will increase. In addition, female directors have an active role and are more accustomed to do multitasking work than male directors. This is also supported by the nature of a woman who is gentle but can also be strict with her subordinates so that it can motivate her subordinates to be better. The result is different from the proportion of women as commissioners which is not proven to affect the performance of sharia insurance business unit.

The results of this study also show that the type of insurance moderates the influence of the size board directors and the proportion of women as directors on the performance of sharia insurance business units in Indonesia. The type of insurance with the different products offered and the different business characteristics can strengthen or weaken the influence of size board directors and the proportion of women as directors to the performance.

Further research is still open on the topic of board governance with different characteristics, different performance measures of sharia insurance and different methodology. For the case in Indonesia itself, as far as researchers know, not many researchers have conducted research on sharia insurance and then compared it with other countries.

\section{LIMITATIONS}

The limitation of this study is the number of independent variables are used, namely the size of directors, the size of the Board of Commissioners, the proportion of women as directors and the proportion of women as commissioners. Other board characteristics have not been used in this study. In addition, this research is limited to sharia insurance business units in Indonesia and has not yet examined on a broader scale. 
Ahmad, N., M. S. Tariq., N. Hamad, and S. Samad. 2014. An exploration of corporate governance and its relation with financial performance: A case study from banking institutions of Pakistan. Arabian Journal of Business and Management Review (Oman Chapter) 4 (1): 103-108.

Al-Amameh, A. 2014. Corporate governance, ownership structure and bank performance in Jordan. International Journal of Economics and Finance 6 (6): 69-81.

AlNemer, H. A. 2016. Governance of insurance firms, A comparative study between the Saudi and the International Insurance Regulations: Empirical findings. International Journal of Academic and Reflection 4 (8): 51-74.

Amore, M. D. and O. Garofalo. 2016. Executive gender, competitive pressures, and corporate performance. Journal of Economic Behaviour Organization 131: 308-327.

Anderson, R. C., D. M. Reeb., A. Upadhyay., and W.Zhao. 2011. The economics of director heterogenity. Financial Management 40: 5-38.

Beasley, M. S. 1996. An empirical analysis of the relation between the board of director composition and financial statement fraud. The Accounting Review 71 (4): 443-465.

Brick, I. E., and N. K. Chidambaran. 2010. Board meetings, committee structure and firm value. Journal of Corporate Finance 16 (4): 533-553.

Cheng, S., J. H. Evans, dan N. J. Nagarajan. 2008. Board size and firm performance: The moderating effects of the market for corporate control. Review of Quantitative Finance and Accounting 31 (2): 121-145.

Cummins, J. D., and R. D. Phillips. 2009. Capital adequacy and insurance riskbased capital systems. National Association of InsuranceCommissioners. https://www.researchgate.net/publication/313198082 downloaded at 5 th July 2020.

Darwis, H. 2009. Corporate governance terhadap kinerja perusahaan. Jurnal Keuangan dan Perbankan 13 (3): 418-430.

Datta, N. 2018. Impact of corporate governance on financial performance: A study on DSE Listed Insurance Companies in Bangladesh. Global Journal of Management and Business Research: Accounting and Auditing 18 (2): 1-8.

Dhouibi, R. 2013. Board of director's characteristics and bank's insolvency risk: Evidence from Tunisia. Developing Country Studies 3 (4): 133-145. 
IQTISHADIA

13,2

Dobbin, F., and J. Jung. 2011. Corporate board gender diversity and stock performance: The competence gap or institutional investor bias? North Carolina Law Review 89: 809-838.

Eisenhardt, K. M. 1989. Agency theory: An assessment and review. The Academy of Management Review 14 (1): 57-74.

Endraswati, H. 2016. Women as board of commissioner dan kinerja perbankan syariah di Indonesia. Yogyakarta. Phoenix Publisher.

Endraswati, H. 2018. Gender diversity in board of directors and firm performance: A study in Indonesia Sharia Banks. Review of Integrative Business and Economics Research 7 (1): 299-312.

Fairfax, L. 2006. Is corporate governance enhanced by women directors? Downloaded from http://www.theconglomerate.org/2006/11/is corporate go.html downloaded on 23th May 2020.

Fekadu, G. W. 2015. Corporate governance on financial performance of insurance industry. Corporate Ownership \& Control 13 (1): 1201-1210.

Fernandez, M. R. 2015. Company financial performance: Does board size matter? Case of Eurostoxx50 Index. Cuadernos de Gestion 15 (2): 15-38.

Firmansyah, I., and A. R. Fadillah. 2019. The role of the board commissioners in improving the financial performance of sharia insurance industries in Indonesia. Advances in Economics, Business and Management Research 100: 341-347.

Frieze, I. H., J. E. Olson, and D. C. Good. 1990. Perceived and actual discrimination in the salaries of male and female managers. Journal of Applied Social Psychology 20 (1): 46-67.

García-Meca, E., I. M. García-Sánchez., J. Martínez-Ferrero. 2015. Board diversity and its effects on bank performance: An international analysis. Journal of Bank Finance 53: 202-214.

Ghozali, I. 2011. Aplikasi Analisis Multivariate dengan Program IBM SPSS. Semarang. Badan Penerbit Universitas Diponegoro.

Handayani, K. 2015. Analisis kinerja keuangan perusahaan BUMN asuransi yang go publik (menggunakan analisis ratio dan risk-based capital). Jurnal Studi Manajemen dan Bisnis 2 (2): 188-202.

Hasbi, H. 2013. Sistem peringatan dini sebagai pendukung kinerja perusahaan Asuransi Syariah. Jurnal Keuangan dan Perbankan 17 (2): 243-252.

Hassan, M., M. Rizwan, and H. M. Sohail. 2017. Corporate governance, shariah advisory boards and Islamic banks performance. Pakistan Journal of Islamic Research 18 (1): 172-185. 
Hidayat, I. P., and I. Firmansyah. 2017. Determinants of financial performance in the Indonesian Islamic Insurance Industry. Etikonomi 16 (1): 1-12.

Hidayat, A. A., and S. Utama. 2015. Board characteristics and firm Type of Insurance performance: Evidence from Indonesia. International Research Journal of Business Studies 8 (3): 137-154.

Houthoofd, N., and J. Hendrickx. 2012. Industry segment effects and firm effects on firm performance in single industry firms. HUB Research Paper Economics and Management. https://www.researchgate.net/ publication/254420787. Downloaded on $29^{\text {th }}$ May 2020

Ibrahim, H. B., C. Ouma., and J. Koshal. 2019. Effect of gender diversity on the financial performance of insurance firms in Kenya. International Journal of Research in Business and Social Science 8 (5): 274-285.

Iunascu, M., I. Iunascu., M. Sacarin., and M. Minu. 2018. Women on boards and financial performance: Evidence from a European Emerging Market. Sustainability 10: 1-18.

Jensen, M., and W. Meckling. 1976. Theory of the firm: Managerial behaviour, agency costs and ownership structure. Journal of Financial Economics 3: 305-360.

Joo, B. A. 2013. Analysis of financial stability of Indian nonlife insurance companies. Asian Journal of Finance and Accounting 5(1): 306-319.

Kader, H. A., M. Adams., P. Hardwick., and W. J. Kwon. 2014. Cost efficiency and board composition under different takaful insurance business models. International Review of Financial Analysis 32: 60-70.

Khan, F., T. Arman., and B. Eneizan. 2019. Impact of corporate governance characteristics on banks performance. International Journal of Academic Management Science Research 3 (8): 1-7.

KMK No. 424/KMK.06/2003. Kesehatan Keuangan Perusahaan Asuransi dan Perusahaan Reasuransi. http://www.ojk.go.id. Downloaded on $23^{\text {rd }}$ June 2020.

Kramaric, T. P., A. Aleksic., and M. Pejic-Bach. 2018. Measuring the impact of board characteristics on the performance of Croatian Insurance Companies. International Journal of Engeenering Business Management 10: 1-13.

Kusumawati, S. M., and A. A. Hermawan. 2013. The influence of board of commissioners and audit committee effectiveness, ownership structure, bank monitoring, and firm life cycle on accounting fraud. Jurnal Akuntansi dan Keuangan Indonesia 10 (1): 20-39. 
IQTISHADIA

13,2

278
Lee, H. S., F. F. Cheng., W. M. Har., A. Md. Nassir., and N. H. Ab. Razak. 2019. Efficiency, firm specific and corporate governance factors of the takaful insurance. International Journal of Islamic and Middle Eastern Finance and Management 12 (3): 368-388.

Leviany, T., and W. Sukiati. 2014. Pengaruh risk-based capital terhadap profitabilitas pada perusahaan asuransi jiwa. Jurnal Aset (Akuntansi Riset) 7 (1): 1-12.

Liu, Y., Z. Wei., and F. Xie. 2014. Do women directors improve firm performance in China. Journal of Corporate Finance 28: 169-184.

Low, D. C. M., H. Roberts., and R. H. Whiting. 2015. Board gender diversity and firm performance: Empirical evidence from Hong Kong, South Korea, Malaysia and Singapore. Pacific Basin Financial Journal 35: 381-401.

Mandira, I. M. C., I. G. A. Putri. M. Asri Dwija. 2014. Analisis komparatif kinerja keuangan Allianz Life Indonesia dengan PT. Prudential Life Assurance. E-Journal Akuntansi Universitas Udayana 8 (2): 152-169.

Marinova, J., J. Plantenga., and C. Remery. 2016. Gender diversity and firm performance: Evidence from Dutch and Danish boardrooms. The International Journal of Human Resource Management 27 (15):1777-1790.

Matyjas, Z. 2014. Industry and firm influences on performance: Evidence from Polish Public Firms. Journal of Management Policy and Practice 15 (2): 88-97.

Memon, M. A., C. H. Cheah., T. Ramayah., H. Ting., F. Chuah., and T. H. Cham. 2019. Moderation analysis: Issues and guidelines. Journal of Applied Structural Equation Modeling 3 (1): i-xii.

Mollah, S., and M. Zaman. 2015. Shari'ah supervision, corporate governance and performance: Conventional vs islamic banks. Elsevier. Licensed under the Creative Commons Attribution-NonCommercial No Derivatives 4.0 International. http://creativecommons.org/licenses/ by-nc-nd/4.o/Downloaded on 3oth June 2020.

Najjar, N. J. 2012. The impact of corporate governance on the insurance firm's performance in Bahrain. International Journal of Learning \& Development 2 (2): 1-18.

Nataraj, R. R. 2020. Does service quality impact relationship quality? Analyzing the moderating effect of demographic variables in the path model empirical evidence from Indian Retail Banks. International Journal of Innovative Technology and Exploring Engineering 9 (3): 239-244. 
Nasution, Z., E. M. Adiba and M. O. Abdulrahim. 2019. Comparison analysis of risk-based capital (RBC) performance and its effect on islamic insurance profitability in Indonesia and Malaysia. Al-Uqud: Journal of Islamic Economics 3 (2): 149-160.

Ning, W., and A. Alikaj. 2019. The influence of age on the Job Resources Engagement Relationship. International Journal of Organization Characteristics, Type of Insurance Analysis March: 1-42.

Ortynski, K. 2016. Determinants of profitability of general insurance Companies performance in Poland. Central European Review of Economics and Finance 12 (2): 53-66.

Patel, R. 2013. Solvency analysis-A study of public and private insurance companies in India. Indian Journal of Applied Research 3 (5): 1-4.

POJK No.2/POJK.05/2014. Tata Kelola Perusahaan yang Baik bagi Perusahaan Perasuransian. http://www.ojk.go.id. Downloaded on $2^{\text {nd }}$ June 2020.

POJK No.73/POJK.05/2016. Tata Kelola Perusahaan yang Baik bagi Perusahaan Perasuransian. http://www.ojk.go.id. Downloaded on $2^{\text {nd }}$ June 2020.

POJK No. 72/POJK.05/2016. Kesehatan Keuangan Perusahaan Asuransi dan Perusahaan Reasuransi dengan Prinsip Syariah. http://www. ojk.go.id. Downloaded on $2^{\text {nd }}$ June 2020.

Pramestika, D. 2019. Pengaruh tingkat kesehatan perusahaan asuransi terhadap pertumbuhan premi neto dan profitabilitas perusahaan. Journal of Economics Development Issues 2 (1): 26-37.

Pramono, N. H. 2019. Maqasid sharia index: Arah baru kinerja keuangan perusahaan asuransi syariah di Indonesia. IJAB 1 (1): 60-76.

Putra, B. P. D. 2015. Pengaruh dewan komisaris, proporsi komisaris independen terhadap kinerja perusahaan. Jurnal Manajemen Teori dan Terapan 8 (2): 70-85.

Putri, A. P., and H. S. Lestari. 2014. Faktor-faktor yang menentukan kinerja perusahaan asuransi yang terdaftar di bursa efek indonesia. E-Journal Manajemen 1 (2): 1-20.

Raza, S. A., M. S. Farooq., and N. Khan. 2011. Firm and industry effects on firm profitability: An empirical analysis of KSE. International Research Journal of Finance and Economics. https//www.researchgate.net/ publication/241766025. Downloaded on $29^{\text {th }}$ May 2020. 
IQTISHADIA

13,2

Robin and N A. Amran. 2016. The effect of board commissioners on family firm performance in Indonesia. Advanced Science Letters 22: 41424145 .

Ruefli, T. W., and R. R. Wiggins. 2003. Industry, corporate and segment effects and business performance: A non-parametric approach. Strategic Management Journal 24: 861-879.

Sanyaolu., O. A. Adesanmi., A. D. Imeokparia., A. O. Sanyaolu., and A. Alimi. 2017. Corporate governance and financial performance of quoted deposit money banks in Nigeria. International Journal of Social Science and Economic Research 2 (8): 4131-4147.

Shabbir,MS. 2018. Women on corporateboards firm performance, preliminary results from Italian Listed Companies after the introduction of gender quota law 120/2011. Journal of Business \& Financial Affairs 7 (1): 1-6.

Sugianto, D. K. 2017. The moderating effect of age, income, gander, expertise, loyalty Program, and critical incident on the influence of customer satisfaction towards customer loyalty in Airline Industry: A case of PT X. iBuss Management 5 (1): 70-83.

Suhardjanto, D. Alwiyah., M. E. Utami., and M. Syafruddin. 2017. Board of commissioner diversity and financial performance: A comparative study of listed mining industry in Indonesia and Pakistan. Review of Integrative Business and Economics Research 6 (1): 131-142.

Suherman, M., I. Firmansyah., and M. Almunawwaroh. 2019. Determinants of sharia insurance company profitability. AFEBI Accounting Review 4 (1): 41-50.

Sumartono and K. A. Harianto. 2018. Kinerja keuangan perusahaan asuransi di Indonesia dan faktor-Faktor yang mempengaruhinya. Future Jurnal Manajemen dan Akuntansi 6 (1):1-14.

Tertius, M. A., and Y. J. Christiawan. 2015. Pengaruh good corporate governance terhadap kinerja perusahaan pada sektor keuangan. Business Accounting Review 3 (1): 223-233.

Tornyeva, K., and T. Wereko. 2012. Corporate governance and firm performance: Evidence from the insurance sector of Ghana. European Journal of Business and Management 4 (13): 95-112.

Ujunwa, A., I. Nwakoby., and C. O. Ugbam. 2012. Corporate board diversity and firm performance: Evidence from Nigeria. Corporate Ownership \& Control 9 (2): 216-227. 
Ulfan, K. 2016. Analisis pengaruh rasio early warning system Board terhadap financial solvency pada Perusahaan Asuransi Jiwa Syariah di Indonesia. Jurnal Penelitian Ilmu Ekonomi 8(1): 12-23.

Utami, E. P., and M. Khoiruddin. 2016. Pengaruh rasio keuangan early warning system terhadap tingkat solvabilitas Perusahaan Asuransi Jiwa Syariah periode 2010-2013. Management Analysis Journal 5 (1): Type of Insurance $55-63$.

Virtanen, A. 2012. Women on boards of listed companies: evidence from Finland. Journal of Managing Governance 16: 571-593.

Widagdo, D. O. K., and A. Chariri. 2014. Pengaruh good corporate governance terhadap kinerja perusahaan. Diponegoro Journal of Accounting 3 (3): 1-9.

Wijayanti, S., and S. Mutmainah. 2012. Pengaruh penerapan corporate governance terhadap kinerja keuangan pada perusahaan perbankan yang terdaftar di Bursa Efek Indonesia (BEI) tahun 2009-2011. Diponegoro Journal of Accounting 1 (2): 1-15.

www.republika.co.id. 2020. Pertumbuhan Asuransi Syariah Turun 2019, tapi Aset Naik. Downloaded on 3rd June 2020.

\section{Appendix}

\section{Classical Assumption Test Results}

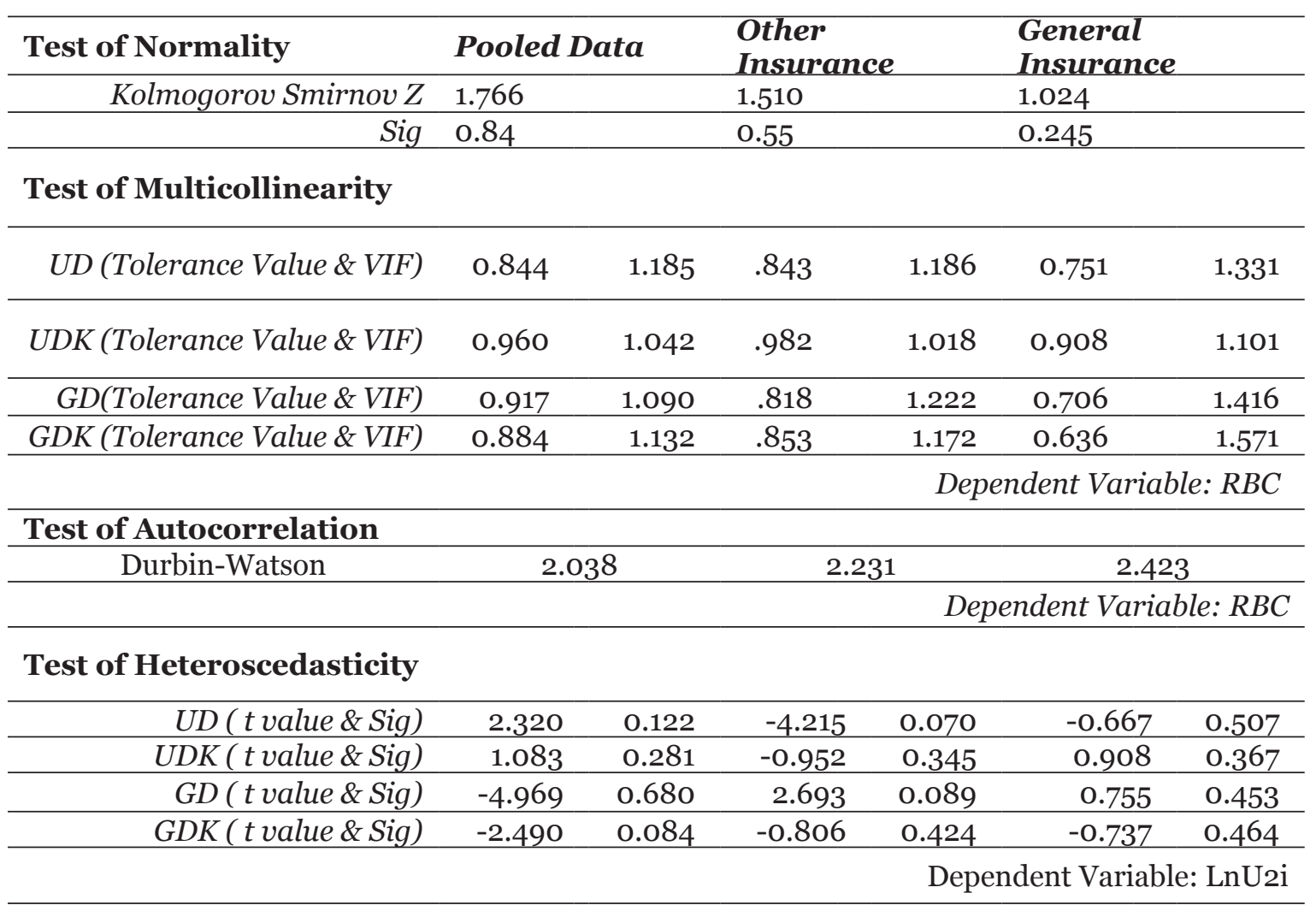

